\title{
Dr. Barry Caplan
}

Cite as: Can Urol Assoc J 2017; Epub ahead of print. http://dx.doi.org/10.5489/cuaj.5008

Published online November 1, 2017

It is with deep sadness that we announce the passing of Barry Caplan on June 2, 2017, at the age of 84, after a short, but courageous, battle with cancer. Dr. Caplan is survived by his loving wife, Sandra, children, Susan Billinkoff (Errol), Bruce Caplan (Sheri Winters), David Caplan (Cindy Switzer), grandchildren, Jordan Billinkoff, Asher Billinkoff, Maia Caplan, Annie Caplan, Max Switzer-Caplan, and Layla Switzer Caplan, as well as many members of his immediate and extended family.

Born in Winnipeg, Dr. Caplan attended the medical school at the University of Manitoba, graduating in 1957. He did a one-year internship at the, then, Winnipeg General Hospital (now the HSC), followed by a fellowship in pathology, again in Winnipeg. After one year in a general surgery residency, he took another fork in the road and started a residency in urology at the UCLA medical school. He completed that residency in June 1963.

Upon completion of my his urology residency, the Caplan family returned home to Winnipeg, where Dr. Caplan built his medical practice, starting first in the Boyd Building and later opening a new office in the Medical Arts together with his friend and fellow urologist, Dr. Allan Decter. He and Dr. Decter shared a long and happy professional association and friendship. In addition to his practice at the Medical Arts, Dr. Caplan served as a urological consultant to the St. Boniface Clinic; he spent most of his operating days at the St. Boniface Hospital. He also participated in the undergraduate and post-graduate teaching program for the Department of Surgery, Urology Section, at the University of Manitoba from 1966 until his retirement in 1999. In 1985, he was appointed as an Assistant Professor, an appointment he also held until his retirement.

Dr. Caplan was known to his patients and the staff with whom he worked as a kind, caring, and compassionate doctor. He was devoted to his patients, worked long hours, and always went the extra mile, ensuring that those under his charge received the best care possible.

In his personal life, Dr. Caplan enjoyed taking in the Winnipeg cultural and art scene (opera, symphony, ballet and theatre), travelling, and spending time with his family and beloved grandchildren.

He will be missed by all whose lives he touched. 